Article

\title{
Jatropha Suppliers as Contributors to the Sustainability of the Production of Bioelectricity in Ecuador
}

\author{
Marilyn A. Muñoz Mayorga ${ }^{1, *}$, Eva Iglesias Martínez ${ }^{1}$ and Natalia Caldés Gómez ${ }^{2}$ \\ 1 Department Economics Applied to Agriculture, Food and Natural Resources, \\ Technical University of Madrid, Madrid 28040, Spain; eva.iglesias@upm.es \\ 2 Energy Systems Analysis Unit, Energy Department, Centre for Research on Energy, \\ Environment and Technology, Madrid 28040, Spain; natalia.caldes@ciemat.es \\ * Correspondence: marilyn.munozm@alumnos.upm.es; Tel.: +34-604-221-849
}

Received: 13 August 2017; Accepted: 22 October 2017; Published: 26 October 2017

\begin{abstract}
The "Jatropha for Galápagos" (JFG) project in Ecuador aims to progressively replace diesel with jatropha oil in the generation of electricity in The Galápagos Islands. Thus, understanding and motivating the participation of jatropha suppliers is a priority for the sustainability of JFG. For this reason, the factors influencing their decision-making to participate in the project have been identified and analyzed using a binomial logit model. The results show that factors found to positively influence the likelihood of participation include, amongst others, the supplier's experience within the project, their participation in local organizations, and the degree of satisfaction with the price of jatropha oil. In addition, children from producer families' collaboration in the harvest of jatropha increases the overall likelihood of participation within the project. Similarly, the distance to the collection center positively influences the chances of participation. Conversely, those suppliers with higher wages and those who declared that jatropha harvest starts in April have a reduced likelihood of participating in the project. The findings obtained from this project can help decision-makers develop new measures to improve the sustainability of the project through initiatives to motivate the participation of jatropha suppliers in the program.
\end{abstract}

Keywords: suppliers; live fencings; jatropha; participation; logit; agroenergy

\section{Introduction}

According to the International Renewable Energy Agency (IRENA), the energy sector is responsible for about $60 \%$ of greenhouse gas emissions [1]. One possible way to combat climate change within this sector consists of supporting the deployment of renewable energies, such as biofuels, as a way to substitute conventional fossil fuels. Besides being a climate change mitigation strategy, promoting bioenergy can also contribute to sustainable development. While securing food and energy supplies are amongst the most serious challenges faced by developing countries, sustainable modern bioenergy can promote agricultural, social, and economic development that will help address these challenges [2].

In this context, some developing countries are promoting bioenergy production through the use of Jatropha curcas as an energetic source, due to its potential social, economic, and environmental positive effects in small-scale production models [3-5]. Examples of such rural electrification projects can be found in developing countries such as Indonesia, Tanzania, Mali, and India [6-10].

In this sense, the Ecuadorian government, concerned with the environmental sustainability of its energy system, launched the Renewable Energy for Galapagos project (ERGAL), whose goal is to eradicate the use of fossil fuels in The Galápagos Islands. For this purpose, the ERGAL project 
implemented the 'Jatropha for Galápagos' pilot project (JFG) whose aim is to use jatropha oil to produce electricity in The Galápagos Islands, to reduce the islands' fossil fuel dependency, and to decrease the risk of diesel spillage in the protected marine area of Galápagos. In Floreana Island, the electricity is currently produced by mixing diesel and jatropha oil (JO), with an approximate mixture percentage of $80 \%$ and $20 \%$ respectively.

The JFG project aims to raise the percentage of JO in the mixture to improve the environmental sustainability of electricity production. Such a goal requires an increase in production of jatropha living fences [11], which are currently harvested by jatropha suppliers. Such suppliers are divided into small producers who harvest jatropha from the living fences on their properties and collectors who harvest them from third-party properties, with prior consent from land-owners. In both cases, jatropha fruits are sold to collection centers located in rural areas, which are part of the JFG project. The marketing of jatropha is still in an incipient stage, currently it is marketed by suppliers and local collectors using prices fixed by the JFG project. Thus, in 2013, the price of the seed was $\$ 0.26 / \mathrm{kg}$ while the price of the fruit was $\$ 0.20 / \mathrm{kg}$ [12]. Jatropha is commonly traded as a fruit $(85 \%)$ as the fruit shelling process is time consuming and does not compensate for the increased price of the seed as opposed to the fruit (information obtained through field work). Therefore, suppliers carry out the production and marketing activities of jatropha, but they are not ultimately the beneficiaries of the bioelectricity that is produced. This is not a common situation, as can be observed in similar rural electrification projects $[6-10,13]$.

In this sense, the willingness of jatropha suppliers to participate in the project is not motivated by the access to electricity, but by the additional income received from selling jatropha. From this viewpoint, jatropha suppliers are key players, and their willingness to participate is a cornerstone for the sustainability of the project, and, most importantly, to increase the production of jatropha oil. Therefore, it is of utmost importance to understand and identify the factors that are likely to influence their decision to participate. As such, this study aims at identifying the socioeconomic factors that determine their decision-making in whether to continue participating in the project or abandon it.

Similar studies have analyzed farmers' participation in particular projects, or the adoption of agro-environmental practices. Most of these studies have used discrete response models such as logit binary models, as this modeling framework allows for estimates to be made of the probability of an individual deciding between one alternative and another [14]. In particular, the binary logit model is widely used to analyze the decision of farmers to participate in environmental programs [15,16], as well as to adopt technology packages [17-20]. However, the application of such models to study the long term sustainability or the abandonment of a project has received less attention. An example of such application is found in [21], where the factors influencing the adoption and abandonment of precision farming were identified for cotton production. Similarly, the adoption and abandonment of organic agriculture was analyzed in [22] through the economic and non-economic factors that influence the decision of participating or abandoning organic agricultural practices. Other similar studies used logit models to analyze farmers' willingness to participate in a training program for the creation of a wetland, and the participation of small farmers in a community rural development project [23,24].

Results of such studies indicate that the decision to adopt or participate is often related to the participants' characteristics $[15,19,21]$, social capital $[16,20,22,24,25]$ production characteristics $[16,18,20,21,24,25]$, and the characteristics of the project $[20,26]$. Consequently, in this project, the jatropha suppliers' decision to participate was analyzed by considering explanatory variables related to the suppliers' characteristics, social capital, production characteristics and perceptions on the characteristics of the project.

In this context, this study contributes to enlarge the existing body of knowledge by using a logit model to analyze the factors influencing the decision-making of jatropha suppliers to participate in a bioenergy rural project. Thus, a better understanding of the underlying factors that determine their willingness to participate may contribute to improving the sustainability of the project by facilitating the continuation and expansion of the JFG project and similar projects. The results obtained from this 
project can help to direct decision-makers in developing measures to guarantee, and even increase, the participation of jatropha suppliers in the JFG project, as well as in similar projects.

\section{Context of the Case Study}

Since 2008, the JFG project has had the ambitious objective of progressively replacing diesel with jatropha oil in the production of bioelectricity in The Galápagos Islands, whilst also improving the wellbeing of small jatropha suppliers of rural areas in Manabí [12]. This dual focus has enabled the 145 inhabitants of Floreana Island to receive less contaminating electricity [27], and 3000 poor rural households located in Manabí to improve their family economy through jatropha sales [12].

As for the socio-economic characteristics of the project beneficiaries, the rural population represents $56 \%$ of Manabí's population [28]. Small-scale and family farming are common characteristics of this rural area, where $63 \%$ of farms belong to small farmers with properties smaller than 10 hectares, representing $9.1 \%$ of the total of the arable land of Manabí [29]. According to a FAO study, such family farms are characterized by having limited access to resources, capital, and land, whilst relying upon family labor, and having limited agricultural or fishery production as their main sources of income [30].

In this region, people older than 24 have been enrolled in the schooling system for an average of six years [31] and in accordance with the Unsatisfied Basic Needs (UBN) poverty indicator, $76.8 \%$ of the households have one or more unsatisfied basic need [32], while 33.4\% live in extreme poverty on less than $\$ 1.48$ per day [33]. Moreover, one relevant social problem is child labor, which is related to high illiteracy rates and low academic levels [34]. Due to these socioeconomic vulnerabilities, small-scale suppliers within rural areas often decide to sell jatropha to improve their family economy.

The literature reports that in other developing countries jatropha production may come from monoculture, associated crops, and living fences [3,35]. In Manabí, all jatropha comes from jatropha fences; according to official records, $7000 \mathrm{~km}$ of jatropha living fences were registered in the rural area of Manabí in 2008 [12]. Traditionally, farmers used jatropha living fences to demarcate their small farms and to prevent animals consuming their food crops. As compared to other biomass production systems, living fences prevent soil erosion, avoid land competition with food crops, and do not threat food security, as jatropha is not edible.

\section{Materials and Methods}

A discrete choice model was used to identify socioeconomic drivers influencing the suppliers' decision to participate in the JFG project. The hypothesis to be verified in this study was: "Price perceptions, incentives for jatropha production, production characteristics, as well as participation in social networks, and suppliers' characteristics have an influence in their decision to participate in the project".

Discrete choice modeling is based on the random utility theory developed by Thurstone and Mc.Fadden [36,37]. This framework assumes that the individual $i$ decides among the set of alternatives $C_{j}$ where $j=1$ (participate) and $j=0$ (not to participate) and the utility or satisfaction, $U_{i j}$, that individual $i$ obtains when choosing a given alternative $j$ is defined as follows:

$$
U_{i j}=v_{i j}+\varepsilon_{i j}
$$

Equation (1) states that utility $U_{i j}$ has two components, a deterministic component $v_{i j}=X_{i j} \beta$, where $X_{i j}$ is a set of observed variables that reflect the characteristics of the alternative and socioeconomic characteristics of the individual; and $\beta$ is the parameter vector that we want to estimate. The second component $\varepsilon_{j i}$ is unknown and treated by the researcher as random.

$U_{i j}$ is the utility (or net benefit) that person $i$ obtains from taking action (in contrast to not taking action). The utility that the person obtains from choosing the alternative $j$ depends on the characteristics of the person and the characteristics of the alternative $j$. 
In this application, we denote $U_{i 1}$, as the utility that individual $i$ obtains if the individual decides to participate $(j=1)$ and $U_{i 0}$, the utility the individual obtains if the individual decides to abandon the project. We assume that the individual chooses the alternative which provides the highest utility or satisfaction. Since an individual's utility cannot be directly observed, the individual decision or willingness to participate or abandon is defined through a binary variable $Y_{i}$ according to the following equation:

$$
Y_{i}\left\{\begin{array}{l}
=1 \text { if } U_{i 1}>U_{i 0} \\
=0 \text { if } U_{i 1}<U_{i 0}
\end{array}\right.
$$

For the set of alternatives $C_{j}:\{j=1$ participates, $j=0$ does not participate $\}$.

From Equations (1) and (2), we are able to define the likelihood of the individual $i$ choosing to participate as:

$$
P\left(y_{i}=1 \mid x_{1} \ldots x_{k}\right)=P\left(U_{i 1} \geq U_{i 0}\right)=\operatorname{Pr}\left(\varepsilon_{i 1}-\varepsilon_{i 0} \geq v_{i 1}-v_{i 0}\right)
$$

Assuming that the error term $\left(\varepsilon_{i 1}-\varepsilon_{i 0}\right)$ follows a logical distribution, we can model the decision to participate through the logical model where $\beta$ is a vector $\left(\beta_{0}, \beta_{1}, \beta_{2} \ldots \beta_{n}\right)$ representing regression parameters to be estimated using the maximum likelihood method.

$$
P_{i}\left(y_{i}=1 \mid x_{1} \ldots x_{k}\right)=\frac{e^{X_{i} \beta}}{\sum_{k=0}^{j} e^{X_{i} \beta}}
$$

\section{Survey Design and Data Collection}

A survey was carried out to collect information from jatropha suppliers and the project to analyze jatropha suppliers' decision to participate in the project, such decision-making is subject to their utility or satisfaction. Preliminary, open semi-structured interviews with several stakeholders were first conducted to identify relevant socio-economic information about jatropha suppliers, as well as information related to the characteristics of the project. A questionnaire was designed based on this information and on case studies reviewed from the literature.

The questionnaire was structured in four blocks of questions. The first block gathered information about socio-demographic characteristics of the suppliers. The second block included questions related to the supplier's social networks. Given the importance of family farming in the area, we explicitly inquired about the participation of adult and child family members in the jatropha harvesting activities. The third block included questions related to farm characteristics, agricultural activity, and jatropha practices. Finally, the fourth block collected economic information of those surveyed their perceptions about the characteristics of the project, and their willingness to continue to participate or to abandon it.

This questionnaire was tested in various communities to avoid ambiguities and to improve the design. In 2014, the participation of jatropha suppliers in 12 communities was registered. As a result, 159 face-to-face interviews were conducted with jatropha suppliers during April and May. Figure 1 presents the location of the 10 surveyed communities in the Manabí province in 2015. The survey sampling was based on a random and simple probabilistic method for finite population sizes, with a total of 724 jatropha suppliers, a $p$ probability of occurrence of 0.5 , a $7 \%$ error percentage and a $95 \%$ confidence interval. 


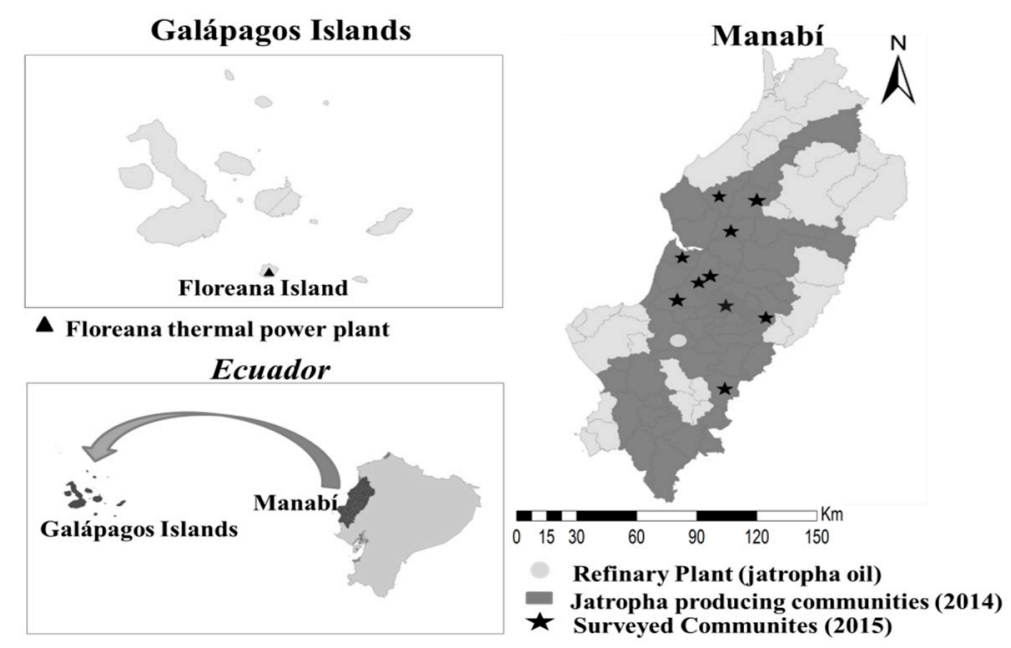

Figure 1. Geographical scope of study.

Table 1 presents the definition and statistical description of the independent variables considered in the model. These variables are classified according to four categories: supplier's characteristics, social capital, farm and production characteristics, and project characteristics. Moreover, by way of hypothesis, the signs $(+/-)$ represent the sign that the coefficient of each variable is expected to have in the model. Hence, a positive (or negative) sign depicts that the variable is expected to have a positive (or negative) influence on the supplier's willingness to participate.

Table 1. Statistics summary of the independent variables related with suppliers' decision to participate.

\begin{tabular}{|c|c|c|c|c|c|c|}
\hline \multirow[b]{2}{*}{$\begin{array}{l}\text { Independent } \\
\text { Variables }\end{array}$} & \multirow[b]{2}{*}{ Definition } & \multicolumn{4}{|c|}{ Estadistics } & \multirow{2}{*}{$\begin{array}{l}\text { Expected } \\
\text { Sign }\end{array}$} \\
\hline & & Mean & Sd. & Min & Max & \\
\hline \multicolumn{7}{|c|}{ Category: Supplier's characteristics } \\
\hline Age & $\begin{array}{l}\text { Age (years) of the supplier }(1 \text { to } 5 ; 1=18-28 \\
2=29-39,3=40-50,4=51-61 \\
5=\geq 62 \text { years })\end{array}$ & 3.1 & 1.33 & 1 & 5 & - \\
\hline Social security & $\begin{array}{l}\text { Social security beneficiary }(1=\text { If the } \\
\text { supplier has social security. } 0=\text { other wise })\end{array}$ & 0.48 & 0.5 & 0 & 1 & - \\
\hline Salary & Supplier's monthly salary in dollars & 211.32 & 80.14 & 80 & 400 & - \\
\hline $\begin{array}{l}\text { Use of jatropha } \\
\text { income }\end{array}$ & $\begin{array}{l}\text { Use of money obtained from selling } \\
\text { jatropha; Categories } 1=\text { household needs, } \\
0=\text { other wise }\end{array}$ & 0.92 & 0.26 & 0 & 1 & + \\
\hline Jatropha producer & $\begin{array}{l}1=\text { If the supplier is a producer of jatropha, } \\
0=\text { other wise }\end{array}$ & 0.67 & 0.47 & 0 & 1 & + \\
\hline Experience & $\begin{array}{l}\text { Participation in the project. ( }>3 \text { years }=1,0 \\
=\text { other wise) }\end{array}$ & 0.68 & 0.47 & 0 & 1 & + \\
\hline \multicolumn{7}{|c|}{ Category: Social capital } \\
\hline $\begin{array}{l}\text { Member of an } \\
\text { organization }\end{array}$ & $\begin{array}{l}1=\text { If the supplier is a member of a local } \\
\text { organization, } 0=\text { other wise }\end{array}$ & 0.38 & 0.49 & 0 & 1 & + \\
\hline $\begin{array}{l}\text { Participation of } \\
\text { women }\end{array}$ & $\begin{array}{l}1=\text { If women participate in jatropha } \\
\text { harvest, } 0=\text { other wise }\end{array}$ & 0.42 & 0.49 & 0 & 1 & $+1-$ \\
\hline $\begin{array}{l}\text { Participation of } \\
\text { children }\end{array}$ & $\begin{array}{l}1=\text { If children participate in jatropha } \\
\text { harvest, } 0=\text { other wise }\end{array}$ & 0.33 & 0.47 & 0 & 1 & $+/-$ \\
\hline \multicolumn{7}{|c|}{ Category: Production characteristics } \\
\hline $\begin{array}{l}\text { Start of jatropha } \\
\text { harvest }\end{array}$ & $\begin{array}{l}\text { Month in which the jatropha harvest begins } \\
\text { in the community of the supplier; } 1=\text { April, } \\
0=\text { other wise. }\end{array}$ & 0.64 & 0.48 & 0 & 1 & - \\
\hline $\begin{array}{l}\text { Jatropha } \\
\text { production }\end{array}$ & $\begin{array}{l}\text { Annual production (quintal) of jatropha } \\
\text { fruits by a supplier }\end{array}$ & 10.5 & 13.5 & 1 & 98 & + \\
\hline Distance & $\begin{array}{l}\text { Distance }(\mathrm{km}) \text { between the jatropha farm } \\
\text { and jatropha collection center }\end{array}$ & 14.42 & 6.87 & 4 & 21 & - \\
\hline
\end{tabular}


Table 1. Cont.

\begin{tabular}{|c|c|c|c|c|c|c|}
\hline \multirow[b]{2}{*}{$\begin{array}{c}\text { Independent } \\
\text { Variables }\end{array}$} & \multirow[b]{2}{*}{ Definition } & \multicolumn{4}{|c|}{ Estadistics } & \multirow{2}{*}{$\begin{array}{l}\text { Expected } \\
\text { Sign }\end{array}$} \\
\hline & & Mean & Sd. & Min & $\operatorname{Max}$ & \\
\hline \multicolumn{7}{|c|}{ Category: Project characteristics } \\
\hline Incentives & $\begin{array}{l}\text { Incentives for jatropha production. } \\
1=\text { If the supplier has received project } \\
\text { incentives, } 0=\text { other wise }\end{array}$ & 0.69 & 0.46 & 0 & 1 & + \\
\hline Perception of price & $\begin{array}{l}\text { Perception of jatropha price satisfaction; } \\
\text { Categories: } 1=\text { very satisfied, } 0=\text { other wise }\end{array}$ & 0.31 & 0.46 & 0 & 1 & + \\
\hline
\end{tabular}

The independent variables included in the model were selected with the aim of explaining the supplier's decision to participate in the JFG project. The independent variables were selected taking into account two complementary criteria: first, key variables were used in similar studies; and second, relevant variables were added taking into account the JFG project's specificities and goals. In this respect, the variables selected based on the literature review were salary, age, membership of an organization, household size, and price perception. It is important to note that these variables were significant in some of the reviewed studies. Additionally, other variables of interest for this study were added, such as social security, family labor participation, type of jatropha supplier, the use of jatropha income received, the start of jatropha harvest, incentives for jatropha production, and the distance between jatropha area production and jatropha center collection. The descriptive statistics related to the variables and the expected signs are detailed below.

$89 \%$ suppliers declared the willingness to participate in the JFG project; with the descriptive statistics of the suppliers' characteristics category showing that nearly half of suppliers $(44.6 \%)$ are between the ages of 40 and $61,34.6 \%$ are between 18 and 39, and $20.8 \%$ are 62 or older. Those suppliers reaching old age could encounter greater limitations to develop activities that require physical efforts such as harvesting, so it is expected that older age individuals are negatively related with participation. Besides, less than half of the suppliers $(47.8 \%)$ claim to have a social insurance. In the rural context, being a beneficiary of social security means having a better quality of life in socioeconomic terms. Therefore, the social security was expected to be negatively associated with the participation.

Monthly salary was asked of the suppliers across five value ranges. Most suppliers (76.7\%) declared to receive a monthly salary between 120 and 280 dollars, while $7.5 \%$ receive $\$ 120$ dollars or less. $92.4 \%$ received less than 360 dollars, which is slightly higher the national monthly average salary (\$354), as registered in 2015 [38]. Only 7.5\% stated that they received 360 dollars or more. Considering that rural people of Manabí are vulnerable to poverty, then it was expected that higher salaries were negatively linked with participation, which means that suppliers who have higher salaries could be less interested in participating.

Given the poverty conditions of many suppliers, the use of incomes from jatropha sales was also asked. $92.4 \%$ of respondents stated that they used jatropha-sourced income to fulfill their basic needs, while the rest declared it was saved, used for leisure activities, or for farming activities. Since the use of jatropha incomes is significant in the suppliers' household economy, the variable was expected to be positively associated with the probability of participate.

Regarding the supplier's characteristics, participants are not required to commit important investments or assume sunk costs to produce the jatropha because they do not have a formal contract to supply a minimum level of production. $67.3 \%$ of respondents declared that they harvested jatropha from living fences on their property, while $32.7 \%$ declared they were jatropha collectors harvesting from other farmers' properties. The producer variable is expected to be positively related to the decision to participate, because they have jatropha living fences on their farms.

With regards to the experience within the JFG project, $68 \%$ of the suppliers have been participants of the project from three to six years, whilst the rest have been members for less than two years. Therefore, the majority of participants who joined the project within the first years of the project could 
have acquired experience and adapted to the jatropha activities and, therefore, the experience was expected to be positively associated with participation.

The social capital category shows information about social networks and the involvement of family members in jatropha activities. In this regard, $38 \%$ of respondents declared to be members of a social local organization. It was expected then that being a member of an organization would be positively related with participation, given that if a supplier is a member of an organization, they could have a higher likelihood to become members of a new organization or participate in social networks.

From the social viewpoint, family farming is little analyzed in logit models. However, the family participation was considered taking into account the social scope of the project. The questionnaire results show that jatropha harvest often involves suppliers' family members, as $41.5 \%$ of suppliers declared that one or more women of the family participate in the jatropha harvest. In addition, $33.3 \%$ of suppliers declared that one or more children in the family collaborated in harvest activities. Given the limited information about this social topic, a possible relationship between this issue and the likelihood of participation is uncertain.

With regards to the production characteristics category, jatropha is harvested during the months of March to May, although the start of the jatropha harvest varies according to the agro-climatic conditions of the different areas. $63.5 \%$ of suppliers declared that jatropha harvest in their communities starts in April. Thus, jatropha, together with other short-cycle crops are harvested in the winter season, which could limit suppliers' availability to collect jatropha. For this reason, the variable of the start of the jatropha harvest was expected to be negatively related with participation.

The scale of the jatropha production supplied to the project each year is highly variable; given that sometimes it is affected by unfavorable climatic conditions or insect infestations. Results show that $69.8 \%$ of the suppliers harvest between 1 and 10 quintals, while $18.9 \%$ harvest between 11 and 20 quintals, and $9.4 \%$ harvest between 21 and 98 quintals, and only $1.9 \%$ of suppliers harvest less than 1 quintal. While most suppliers have a small annual jatropha production, which could reveal their vulnerability to poverty, there is a small minority of participants with higher production. Thus, all suppliers benefit to varying degrees by jatropha production. Therefore, jatropha production was expected to be positively associated with likelihood of participation.

The distance between jatropha production areas and jatropha collection centers where jatropha fruits are sold ranges from 7 to $21 \mathrm{~km}$. Such distances are important, not only in relation with technical aspects but could also reveal information related to the social issues of suppliers who live in distant areas and commonly are more vulnerable to social exclusion and are more likely to suffer extreme poverty. Besides, for the largest distance, the suppliers could have more difficulty to transport the jatropha. For this reason, the distance was expected to be negatively related with participation.

The category characteristic of the project collects information about the contributions and benefits of the project. Regarding the incentives received for increasing the jatropha annual production, $30.2 \%$ of suppliers declared to have received one or more incentives. Amongst the most common incentives are jatropha vegetative material, wire rolls, and kits for jatropha harvest. It should be noted that the jatropha production is promoted only through the use of living fences system in order to comply with the sustainability approach adopted by the project. Given that the main objective of incentives is to increase the jatropha production and suppliers' participation, the incentives variable was expected to be positively linked with participation.

Additionally, the price perception of jatropha fruits and seeds was asked, with $31.4 \%$ of suppliers declaring they are very satisfied with the jatropha fruit or seed price. $64.2 \%$ of the suppliers declared being satisfied and $4.4 \%$ declared being little satisfied. As price is often a significant motivation factor, therefore the price perception was expected to be positively associated with the likelihood of participation. 


\section{Results and Discussion}

Some statistical tests were conducted to validate our model. First, a multicollinearity test was considered to measure the strength of the interrelationships among the independent variables. For this purpose, two indicators were used: Tolerance $\left(1-R^{2}\right)$ which indicates how much collinearity a regression analysis can tolerate and Variance Inflation Factor (VIF), which is 1/Tolerance and indicates how much of the inflation of the standard error could be caused by collinearity. As a reference, Tolerance values smaller than 0.1 and VIF values greater than 10, suggest that multicollinearity is an issue [15]. Table 2 shows the Tolerance and VIF indicators for the explanatory variables of the model indicating that multicollinearity is not an issue.

Table 2. Multicollinearity diagnosis for independent variables.

\begin{tabular}{ccc}
\hline Variables & VIF & Tolerance \\
\hline Age & 1.18 & 0.85 \\
Social security & 1.50 & 0.67 \\
Salary & 1.63 & 0.61 \\
Use of jatropha income & 1.10 & 0.91 \\
Jatropha producer & 1.45 & 0.69 \\
Experience & 1.21 & 0.82 \\
Member of an organization & 1.44 & 0.69 \\
Participation of women & 1.69 & 0.59 \\
Participation of children & 1.53 & 0.65 \\
Start of jatropha harvest & 1.20 & 0.83 \\
Jatropha production & 1.41 & 0.71 \\
Distance & 2.25 & 0.45 \\
Incentives & 1.21 & 0.82 \\
Perception of price & 1.25 & 0.80 \\
\hline
\end{tabular}

The results of the logistic model that analyzes the jatropha suppliers' decision to participate are shown in Table 3, where the coefficients, odds ratio, and marginal effects of all variables are shown. The interpretation of results is realized through marginal effects that are described below. Additionally, the chi-square reveals that the likelihood ratio statistics are significant, indicating that the model has a strong explanatory power and confirms that suppliers' decision to participate is based on the identified variables.

The pseudo $R^{2}$ value indicates the extent to which a logit function fits the datasets. In this respect, a value equal to 1 signifies a perfect fit and a value equal 0 means no relationship [15].

The pseudo $R^{2}$ value estimated was 0.37 and values greater than 0.2 represent a relatively good fit $[15,18]$. Prediction success statistics indicate the percentage of observations the model can predict correctly, which for this work was $91.8 \%$. As to the potential specification errors, the Stata link test was performed in order to check if there is a model specification error. The results show no evidence of such a specification error. Also, to verify the statistical significance of the model, the Hosmer-Lemeshow test in groups of 10 [39] was conducted, and a Prob > chi2 $=0.67$ was obtained, that indicates the model is significant statistically.

Regarding the suppliers' characteristics, the marginal effect of salary suggests that per every dollar increase in salary, the probability of participation in the project is reduced by $0.02 \%$. This implies that suppliers with higher wages are less likely to participate because their opportunity cost is greater and jatropha would be an unprofitable alternative. On the contrary, for those suppliers with lower wages, jatropha represents an opportunity to improve their family economy. These results are aligned with the social objective of the project, which is to encourage the participation of the most vulnerable groups of rural Manabí. These results are also in line with previous studies aimed at better understanding technology adoption by small farmers, where salary levels were found to be a driver in the adoption of a crop association system in rubber farms [19], as well as in the adoption of GIS tools [18]. 
Table 3. Factors that influence the suppliers' decision to participate.

\begin{tabular}{ccccccc}
\hline Variables & Coef. & Std. Err. & $\mathbf{z}$ & $\mathbf{P}>\mathbf{z}$ & Odds Ratio & Marginal Effects \\
\hline Age & -0.176 & 0.268 & -0.650 & 0.513 & 0.839 & -0.0035 \\
Social security & -1.218 & 0.992 & -1.230 & 0.219 & 0.296 & -0.0261 \\
Salary & $-0.011^{* *}$ & 0.005 & -2.310 & 0.021 & 0.989 & -0.0002 \\
Use of jatropha income & -0.668 & 1.155 & -0.580 & 0.563 & 0.513 & -0.0102 \\
Jatropha producer & 0.008 & 0.826 & 0.010 & 0.993 & 1.008 & 0.00015 \\
Experience & $2.218^{* * *}$ & 0.712 & 3.120 & 0.002 & 9.191 & 0.07518 \\
Member of a organization & $1.716^{*}$ & 0.937 & 1.830 & 0.067 & 5.560 & 0.03122 \\
Participation of women & -0.086 & 0.758 & -0.110 & 0.910 & 0.918 & -0.0017 \\
Participation of children & $2.230^{* *}$ & 0.886 & 2.520 & 0.012 & 9.302 & 0.03697 \\
Start of jatropha harvest & $-3.922^{* *}$ & 1.658 & -2.370 & 0.018 & 0.020 & -0.0778 \\
Jatropha production & -0.010 & 0.023 & -0.430 & 0.668 & 0.990 & -0.0002 \\
Distance & $0.139^{* *}$ & 0.055 & 2.510 & 0.012 & 1.149 & 0.00275 \\
Incentives & 1.593 & 1.270 & 1.250 & 0.210 & 4.919 & 0.02558 \\
Perception of price & $2.093^{* * *}$ & 0.784 & 2.670 & 0.008 & 8.109 & 0.03345 \\
Constant & $4.499 *$ & 2.555 & 1.760 & 0.078 & 89.956 & \\
\hline
\end{tabular}

${ }^{*} p<0.1 ;{ }^{* *} p<0.05 ;{ }^{* *} p<0.01$; Likelihood ratio: $\mathrm{chi}^{2}=28.53$. Prob $>\mathrm{chi}^{2}=0.01 . \quad(\mathrm{gl}=14) ;$ Pseudo $R^{2}=0.37$;

Predictive capacity $=91.8 \% . N=159$.

As for "experience", its marginal effect has a positive effect on the participation decision. In this respect, suppliers who have three or more years within the project were $7.52 \%$ more likely to continue participating, than those who have less than a year's experience. The suppliers' years of experience in the project increase their knowledge about jatropha agricultural practices and jatropha marketing. Furthermore, these may strengthen the degree of confidence and familiarity towards the project. Some related studies have also shown the effect of producer experience on agricultural activities in increasing the probability of measure adoption, such as jatropha cultivation [25], adopting measures related to climate change [15], and adopting agricultural conservation practices [40].

Further, the results show that the marginal effect of suppliers who are "members of an organization" in the community has a positive effect as, compared to those who were not members of an organization, they were $3.12 \%$ more likely to participate in the project. This result confirms other studies which show that farmers who are members of social organizations are more likely to participate in rural development projects and community farming projects [24]. A further study also analyzed the adoption of conservation agriculture across 31 case studies and concluded that organization membership significantly influences the probability of adopting conservation agriculture [40].

Furthermore, the marginal effect for the "participation of children in jatropha harvest" variable shows that suppliers whose children (one or more) collaborate in the collection of jatropha fruits are $3.70 \%$ more likely to participate in the project than those who do not receive help from their children. In this regard, it is important to note that one-third of the suppliers received assistance from children in their jatropha harvesting activities. While this type of participation can be framed within the concept of family farming and it is a common practice in the rural context of developing countries, it could have an undesirable effect on schooling rates. This could exacerbate the vulnerability of rural children to having poor educational outcomes, given that the rural area of Manabí has below average years of schooling. It is important to note therefore that there is a period of overlap between the jatropha harvest and beginning of the school year. Additionally, UNESCO indicates that children belonging to vulnerable families, especially, within rural areas, are initiated into labor activities from a very early age in order to contribute to the sustenance of the family, and for this reason, many of them decide to leave school [41]. It should also be noted that this study does not analyze nor measure the participation/type of contribution that children give within the project.

The marginal effect of "start of jatropha harvest" indicates that, compared to the rest, suppliers who reported that jatropha harvest starts in April in their communities are $7.78 \%$ less likely to continue to participate. One possible explanation is the overlap of harvest calendars. While short-cycle crops (corn, peanuts, rice, and beans amongst others) are sown in January [42] and harvested from April 
onwards, the harvesting period for jatropha is from March to May [43]. This could drive jatropha suppliers away from Jatropha and devote their time to more profitable short-cycle crops.

As for the influence of distance from the jatropha production area to the collection center, the marginal effect of the "distance" variable influences the decision to continue participating in the project but not in the way initially expected. The marginal effect suggests that per every kilometer increased, the probability of participation in the project would increase by $0.28 \%$. While this result may seem surprising, we should note that jatropha collection centers are normally located in rural areas with a higher concentration of inhabitants, such as the center of the villages. Thus, nearby suppliers have more work opportunities compared to the suppliers who are further away from the collection centers. The latter suppliers are commonly located in areas isolated from economic activities, with less opportunities and may use jatropha crops as an opportunity to obtain an additional income. This finding implies the need to consider the strategic geographic coverage of the project; particularly focusing on isolated areas to engage with providers who are willing to participate and to expand the supply of jatropha.

Finally, as to the effect of the suppliers' perception of jatropha price, its marginal effect shows a positive effect on the decision to participate. In particular, those suppliers who consider jatropha price to be very satisfactory were $3.35 \%$ more likely to participate in the project than those who declared different perceptions. Therefore, a greater number of suppliers with a very satisfactory perception of price jatropha could contribute to increase the jatropha supply and expand the use of jatropha oil to other islands of Galapagos.

\section{Conclusions}

The production of jatropha is carried out by the suppliers of the JFG project in order to produce bioelectricity in the Galápagos Islands. This initiative helps generate a positive social and environmental impact. However, our fieldwork revealed that the suppliers' interest in jatropha harvest has remained stable or even decreased during recent years. For this reason, measures must be implemented to promote jatropha production and participation of jatropha suppliers, in order to expand the use of renewable energy in Galapagos and guarantee the long-term sustainability of the project. From the results obtained, a number of recommendations can be suggested to promote the future participation of jatropha suppliers.

First, the results indicate that more vulnerable suppliers and those with lower salaries are more likely to participate in the project. These results illustrate the relevance of the social scope of the project, which benefits segments of the population who are extremely vulnerable to poverty, and generates an additional source of income used to supply their basic needs. Additionally, the suppliers' experience in the project and belonging to a local organization are factors that positively influence the decision to participate. Consequently, this information suggests that measures to promote social capital and the strengthening of jatropha suppliers' cooperatives are key elements to enhance the farmers' position in the value chain, thus increasing trust and their willingness to participate in the project.

Second, while family farming is a central element of the project, the participation and contribution of children in jatropha harvest deserves further analysis to prevent child labor and early school drop-outs, a common situation for children who belong to households in rural areas in developing countries. Thus, it is recommended that necessary measures be put in place to prevent child labor. This is particularly relevant during the jatropha harvesting period, which overlaps with the schooling period. Furthermore, it would be advisable to implement mechanisms that involve educational activities for children so as to improve the wellbeing of the members of the community.

Third, the development of jatropha varieties with longer harvesting periods would avoid the overlap with the short-cycle crops calendar, and would create jobs during idle periods. In addition, strategies aimed at improving yields would translate into enhanced profitability, making jatropha more attractive to farmers. Furthermore, our results show that producers in economically deprived and distant locations are more likely to participate in the project. Thus, it is recommended to study 
optimal collection strategies, and to locate collection centers closer to remote areas where suppliers are more willing to participate.

Fourth, as expected, jatropha price has proven to be a relevant factor regarding the suppliers' decision to participate. An increase in jatropha price would make harvesting more attractive to farmers and promote the expansion of jatropha production. However, a price increase may hinder the competitiveness of jatropha as source of energy to substitute diesel in the Galapagos Islands and may threaten the economic viability of the project.

Our findings may offer some guidance to boost the participation of jatropha suppliers, and improve the social impact of the project. Lastly, while this study has identified some of the factors that influence the suppliers' decision to participate, it is necessary to go one step further and use these results to develop and implement strategies to enhance the suppliers' participation to contribute to the sustainability of the JFG project, and guarantee its objectives.

Acknowledgments: This work was carried out with the funding of Secretary of Higher Education, Science, Technology and Innovation (Senescyt) and the guide of the Energy System Analysis Unit at Centre for Energy, Environment and Technology (Ciemat) and the Research Center for Agricultural and Environmental Risk Management at the Technical University of Madrid (Ceigram-UPM), in addition to the support of the institutions that cooperate with "Jatropha for Galapagos" pilot project in Ecuador.

Author Contributions: Marilyn Muñoz has collected processed and interpreted data and has written the manuscript. Eva Iglesias supervised the development of the work and has re-analyzed the data, she has further revised and improved the paper. Natalia Caldés carried out a detailed revision of the paper.

Conflicts of Interest: The authors declare no conflict of interest.

\section{References}

1. International Renewable Energy Agency (IRENA). Roadmap for a Renewable Energy Future [Internet]. 2016. Available online: http://www.irena.org/DocumentDownloads/Publications/IRENA_REmap_2016_ edition_report.pdf (accessed on 24 January 2017).

2. Global Energy Partnership (GBEP). The Global Bioenergy Partnership Sustainability Indicators for Bioenergy, 2011. Available online: http:/ / www.globalbioenergy.org/fileadmin/user_upload/gbep/docs/Indicators/ The_GBEP_Sustainability_Indicators_for_Bioenergy_FINAL.pdf (accessed on 2 October 2016).

3. Kumar, A.; Sharma, S. An evaluation of multipurpose oil seed crop for industrial uses (Jatropha curcas L.): A review. Ind. Crops Prod. 2008, 28, 1-10. [CrossRef]

4. Eckart, K.; Henshaw, P. Jatropha curcas L. and multifunctional platforms for the development of rural sub-Saharan Africa. Energy Sustain. Dev. 2012, 16, 303-311. [CrossRef]

5. Achten, W.M.J.; Almeida, J.; Fobelets, V.; Bolle, E.; Mathijs, E.; Singh, V.P.; Tewari, D.N.; Verchot, L.V.; Muys, B. Life cycle assessment of Jatropha biodiesel as transportation fuel in rural India. Appl. Energy 2010, 87, 3652-3660. [CrossRef]

6. Gaul, M. An analysis model for small-scale rural energy service pathways-Applied to Jatropha-based energy services in Sumbawa, Indonesia. Energy Sustain. Dev. Int. Energy Initiat. 2012, 16, 283-296. [CrossRef]

7. Grimsby, L.K.; Aune, J.B.; Johnsen, F.H. Human energy requirements in Jatropha oil production for rural electrification in Tanzania. Energy Sustain. Dev. 2012, 16, 297-302. [CrossRef]

8. Bouffaron, P.; Castagno, F.; Herold, S. Straight vegetable oil from Jatropha curcas L. for rural electrification in Mali-A techno-economic assessment. Biomass Bioenergy 2012, 37, 298-308. [CrossRef]

9. Gmünder, S.M.; Zah, R.; Bhatacharjee, S.; Classen, M.; Mukherjee, P.; Widmer, R. Life cycle assessment of village electrification based on straight jatropha oil in Chhattisgarh, India. Biomass Bioenergy 2010, 34, 347-355. [CrossRef]

10. Portugal-Pereira, J.; Nakatani, J.; Kurisu, K.H.; Hanaki, K. Comparative energy and environmental analysis of Jatropha bioelectricity versus biodiesel production in remote areas. Energy 2015, 83, 284-293. [CrossRef]

11. Renewable Energy for Galapagos (ERGAL). Replacement of Fossil Fuels by Biofuels in the Generation of Electric Energy in Floreana Island, 2008. Available online: http:/ /www.ergal.org/imagesFTP/7734.Estudio_ de_Factibilidad_para_el_Uso_de_Bicombustibles.pdf (accessed on 22 December 2015). 
12. Inter-American Institute for Cooperation on Agriculture (IICA). Systematization of Experiences of the "Piñón para Galápagos" Project, 2013. Available online: http:/ / argus.iica.ac.cr/Esp/regiones/andina/Ecuador/ Documentos\%20de\%201a\%20Oficina/sistematizacion_proyecto_pinon.pdf (accessed on 20 December 2015).

13. Tokunaga, K.; Konan, D.E. Home Grown or Imported? Biofuels Life Cycle $\{\mathrm{GHG}\}$ Emissions in Electricity Generation and Transportation. Appl. Energy 2014, 125, 123-131. [CrossRef]

14. Wooldridge, J.M. Introductory Econometrics, 5th ed. Available online: http://economics.ut.ac. ir/documents/3030266/14100645/Jeffrey_M._Wooldridge_Introductory_Econometrics_A_Modern_ Approach_2012.pdf (accessed on 1 March 2016).

15. Jin, J.; Wang, X.; Gao, Y. Gender differences in farmers' responses to climate change adaptation in Yongqiao District, China. Sci. Total Environ. 2015, 538, 942-948. [CrossRef] [PubMed]

16. Unay Gailhard, I.; Bojnec, S. Farm size and participation in agri-environmental measures: Farm-level evidence from Slovenia. Land Use Policy 2015, 46, 273-282. [CrossRef]

17. Mariano, M.J.; Villano, R.; Fleming, E. Factors influencing farmers' adoption of modern rice technologies and good management practices in the Philippines. Agric. Syst. 2012, 110, 41-53. [CrossRef]

18. Banerjee, S.B.; Martin, S.W.; Roberts, R.K.; Larkin, S.L.; Larson, J.A.; Paxton, K.W.; English, B.C.; Marra, M.C.; Reeves, J.M. A Binary Logit Estimation of Factors Affecting Adoption of GPS Guidance Systems by Cotton Producers. J. Agric. Appl. Econ. 2008, 40, 345-355. [CrossRef]

19. Iqbal, S.M.M.; Ireland, C.R.; Rodrigo, V.H.L. A logistic analysis of the factors determining the decision of smallholder farmers to intercrop: A case study involving rubber-tea intercropping in Sri Lanka. Agric. Syst. 2006, 87, 296-312. [CrossRef]

20. Jogo, W.; Karamura, E.; Tinzaara, W.; Kubiriba, J.; Rietveld, A. Determinants of Farm-Level Adoption of Cultural Practices for Banana Xanthomonas Wilt Control in Uganda. J. Agric. Sci. 2013, 5, 70. [CrossRef]

21. Walton Jonathan, C.; Lambert Dayton, M.; Roberts Roland, R.K.; Larson, J.A.; English Burton, C.; Larkin Sherry, L.; Martin Steven, W.; Marra Michele, C.; Paxton Kenneth, W.; Reeves Jeanne, M. Adoption and Abandonment of Precision Soil Sampling in Cotton Production [Internet]. 2008. Available online: https:/ / www.researchgate.net/publication/46534264_Factors_Influencing_Farmer_Adoption_of_ Portable_Computers_for_Site-Specific_Management_A_Case_Study_for_Cotton_Production (accessed on 17 October 2016).

22. Läpple, D. Adoption and Abandonment of Organic Farming: An Empirical Investigation of the Irish Drystock Sector. J. Agric. Econ. 2010, 61, 697-714. [CrossRef]

23. Söderqvist, T. Are farmers prosocial? Determinants of the willingness to participate in a Swedish catchment-based wetland creation programme. Ecol. Econ. 2003, 47, 105-120. [CrossRef]

24. Alhaji Jamilu, A.; Atala, T.K.; Akpoko, J.G.; Sanni, S.A. Factors Influencing Smallholder Farmers Participation in IFAD-Community Based Agricultural and Rural Development Project in Katsina State. J. Agric. Ext. 2015, 19, 93. [CrossRef]

25. Soto, I.; Achten, W.M.J.; Muys, B.; Mathijs, E. Who benefits from energy policy incentives? The case of jatropha adoption by smallholders in Mexico. Energy Policy 2015, 79, 37-47. [CrossRef]

26. Arifin, B.; Swallow, B.M.; Suyanto, S.; Coe, R.D. A conjoint analysis of farmer preferences for community forestry contracts in the Sumber Jaya Watershed, Indonesia. Ecol. Econ. 2009, 68, 2040-2050. [CrossRef]

27. Cayot, L.J.; Cruz, D.; Knab, R.; Alvarez, M.F.; Perlmutter, M.; Jaramillo, P.M. Informe Galápagos 2011-2012 [Internet]. Galápagos-Ecuador. 2013. Available online: http://www.darwinfoundation.org/media/ filer_public/88/9b/889b7fd7-0a35-4811-91b7-0ad0e04a38db/informe_galapagos_2011-2012_spanish.pdf (accessed on 28 July 2016).

28. National Institute of Statistics and Census (INEC). Censo de Población y Vivienda. Instituto Nacional de Estadistcias y Censos, 2010 [Internet]. 2010. Available online: www.ecuadorencifras.gob.ec/base-de-datoscenso-de-poblacion-y-vivienda/ (accessed on 23 September 2016).

29. National Institute of Statistics and Census (INEC). III Natural Agricultural Census, 2010. Available online: http:/ / anda.inec.gob.ec/anda/index.php/catalog/266 (accessed on 23 November 2016).

30. Luciano, M. La Agricultura Familiar en el Ecuador. Informe del Proyecto Análisis de la Pobreza y de la Desigualdad en América Latina Rural; Serie de Documentos de Trabajo N 147; RIMISP (Centro Latino Americano para el Desarrollo Rural): Santiago, Chile, 2013.

31. National Institute of Statistics and Census (INEC). Booklet of Manabí Province, 2010. Available online: http:/ / www.inec.gob.ec/cpv/descargables/fasciculos_provinciales/manabi.pdf (accessed on 19 July 2016). 
32. National Institute of Statistics and Census (INEC). El Empleo Indígena en el Ecuador, una Mirada a su Situación y Estado de Ánimo Laboral. 2012. Available online: http:/ /www.inec.gob.ec/inec/revistas/eanalisis3.pdf (accessed on 18 January 2017).

33. Ministry of Economic and Social Inclusion (MIES). Interconnected Registration of Social Programs, 2014. Available online: http:/ / www.inclusion.gob.ec/programas-y-servicios/ (accessed on 6 February 2017).

34. Inter-American Institute for Cooperation on Agriculture (IICA). Local Production of Jatropha Oil from Living Fences to Be Used in an Electric Generation Pilot Plan on Floreana Island; IICA: San José, Costa Rica, 2008.

35. Van Eijck, J.; Romijn, H.; Balkema, A.; Faaij, A. Global experience with jatropha cultivation for bioenergy: An assessment of socio-economic and environmental aspects. Renew. Sustain. Energy Rev. 2014, 32, 869-889. [CrossRef]

36. Thurstone, L.L. A law of comparative judgment. Psychol. Rev. 1927, 34, 273-286. [CrossRef]

37. McFadden, D. Conditional logit analysis of qualitative choice behavior. In Frontiers in Econometrics; Wiley: New York, NY, USA, 1973; pp. 105-142. [CrossRef]

38. Ministtry of Labor (MDT). Strategic Institutional Plan, 2015-2018. Quito-Ecuador. 2015. Available online: http:/ / www.trabajo.gob.ec/wp-content/uploads/2015/07/Plan-Estrategico_Final-2015-2018.pdf (accessed on 15 September 2016).

39. Hosmer David, W.J.; Lemeshow, S.; Sturdivant, R.X. Introduction to the Logistic Regression Model. In Applied Logistic Regression; John Wiley \& Sons, Inc.: Hoboken, NJ, USA, 2013; pp. 1-33. Available online: http: / / dx.doi.org/10.1002/9781118548387.ch1 (accessed on 1 September 2016).

40. Knowler, D.; Bradshaw, B. Farmers' adoption of conservation agriculture: A review and synthesis of recent research. Food Policy 2007, 32, 25-48. [CrossRef]

41. Unit Nactions Educational, Scientific and Cultural Organization and Regional Office for Education in Latin America and the Caribbean (UNESCO/OREALC). Educational Situation of Latin America and the Caribbean. Towards quality education for all by 2015 Orealc/Unesco. 2013. Available online: http:/ / www.unesco.org/ new/fileadmin/MULTIMEDIA/FIELD/Santiago/images/SITIED-espanol.pdf (accessed on 1 July 2016).

42. Marcelo Castro, A. Rendimientos de Maíz Duro Seco en el Ecuador Invierno 2015 [Internet]. Quito-Ecuador. 2015. Available online: http:/ / sinagap.agricultura.gob.ec/pdf/estudios_agroeconomicos/rendimiento_ maiz_duro_seco_invierno2016.pdf (accessed on 2 July 2016).

43. Inter-American Institute for Cooperation on Agriculture and National Institute of Agricultural Research (IICA-INIAP). Manual de Cosecha y Post Cosecha de Piñon [Internet]. 2013. Available online: http:/ /legacy. iica.int/Esp/regiones/andina/Ecuador/DocumentosdelaOficina/Manual_de_poscosecha.pdf (accessed on 24 March 2016).

2017 by the authors. Licensee MDPI, Basel, Switzerland. This article is an open access article distributed under the terms and conditions of the Creative Commons Attribution (CC BY) license (http:/ / creativecommons.org/licenses/by/4.0/). 